\title{
VALUE-SENSITIVE CLINICAL ACCOMPANIMENT IN COMMUNITY NURSING SCIENCE
}

Authors:

Sonya Beukes ${ }^{1}$

Anna G.W. Nolte ${ }^{1}$

Ebin Arries ${ }^{1}$

\section{Affiliations:}

${ }^{1}$ Nursing Department,

University of Johannesburg, South Africa

\section{Correspondence to:}

Sonya Beukes

\section{email:}

sbeukes@uj.ac.za

Postal address:

Department of Nursing,

PO Box 524, Auckland Park

2006, South Africa

\section{Keywords:}

clinical accompaniment; clinical practice; community nursing practice; values; value sensitivity

\section{Dates:}

Received: 17 Aug. 2009

Accepted: 12 July 2010

Published: 05 Nov. 2010

How to cite this article: Beukes, S., Nolte, A.G.W. \& Arries, E., 2010,

'Value-sensitive clinical accompaniment in community nursing science', Health $S A$ Gesondheid 15(1), Art. \#485, 7 pages. DOI: $10.4102 /$ hsag. v15i1.485

This article is available at:

http:/ / www.hsag.co.za

(C) 2010. The Authors. Licensee: OpenJournals Publishing. This work is licensed under the Creative Commons Attribution License.

\section{ABSTRACT}

Clinical community health facilities where undergraduate students are placed for their practical work in community nursing science are dynamic and have undergone major transformation over the past few years. In the clinical field, community nurses and undergraduate students are representative of the different races and language and ethnic groups in the South African population, with each group espousing different value systems. Both parties - students and community nurses - report that, due to these differences, value conflicts are experienced during clinical accompaniment and that this has negative effects on clinical learning in community nursing science.

The goal of this study was to explore and describe the experiences of students with regard to value-sensitive clinical accompaniment in the community nursing environment. An exploratory, descriptive and contextual design was used. Interactions between community nurses and students during clinical accompaniment were explored for value sensitivity by means of video recordings, participant observation and focus group interviews. Data were collected by means of video recordings, participant observation and focus group interviews. The data were analysed and coded by the researcher and the external coder, using an inductive descriptive method to identify important segments of the regularity of behaviour. The focus group interviews were transcribed, analysed and coded by the researcher and the external coder, using Tesch's steps of analysis (Creswell 1994:155-156). Lincoln and Guba's criteria (1985:290) for trustworthiness were applied to the study.

The general findings indicate that clinical accompaniment in community nursing is not value sensitive and, as a result, guidelines for value-sensitive clinical accompaniment need to be developed for undergraduate students in the community nursing environment. The following values (values for which guidelines need to be developed) were identified: respect during clinical accompaniment, value-sensitive communication and sensitivity to the quality of clinical accompaniment.

\section{OPSOMMING}

Kliniese gemeenskapsgesondheidsfasiliteite waar voorgraadse studente geplaas word vir gemeenskapsverpleegkundepraktika is dinamies en het groot veranderinge oor die laaste paar jare ondergaan. In die kliniese veld verteenwoordig gemeenskapsverpleegkundiges en voorgraadse studente verskillende rasse en taal- en etniese groepe in die Suid-Afrikaanse bevolking, elkeen met verskillende waardes. Albei partye - studente en gemeenskapsverpleegkundiges - het gerapporteer dat waardekonflik weens verskillende kulture en waardes tydens kliniese begeleiding ervaar word, wat kliniese leer op sy beurt in gemeenskapsverpleegkunde negatief beïnvloed.

Diedoelvandiestudiewasom diebelewenisvanstudentemetbetrekking totwaardesensitiewekliniese begeleiding in gemeenskapsverpleegkunde te verken en te beskryf. ' $n$ Verkennende, beskrywende en kontekstuele ontwerp is gebruik. Die interaksie wat tussen die gemeenskapsverpleegkundiges en studente tydens kliniese begeleiding plaasgevind het, is vir waardesensitiwiteit deur middel van video-opnames, deelnemerobservasie en fokusgroeponderhoude verken. Die data wat deur middel van video-opnames en deelnemerobservasie ingesamel is, is deur die navorser en 'n eksterne kodeerder ontleed en gekodeer.'n Induktiewe beskrywende metode is gebruik om belangrike segmente van die gereeldheid van gedrag te identifiseer en beskryf. Fokusgroeponderhoude is deur die navorsers en ' $n$ eksterne kodeerder getranskribeer, ontleed en gekodeer deur gebruik te maak van Tesch se stappe van analise (Creswell 1994:155-156). Lincoln en Guba (1985:290) se kriteria vir geloofwaardigheid is in die studie gebruik.

Die algemene bevindinge dui daarop dat kliniese begeleiding in gemeenskapsverpleegkunde nie waarde-sensitief is nie. Gevolglik moet riglyne vir waarde-sensitiewe kliniese begeleiding vir voorgraadse studente in gemeenskapsverpleegkunde ontwikkel word. Die volgende waardes (waardes waarvoor riglyne ontwikkel moet word) is geïdentifiseer, naamlik respek tydens kliniese begeleiding, waarde-sensitiewe kommunikasie en sensitiwiteit vir gehalte van kliniese begeleiding.

\section{INTRODUCTION}

\section{Background and rationale}

Clinical education forms an integral part of nursing education in the process of facilitating the integration of theory and practice (Chan 2002:69; McCarty \& Higgins 2003:89-90). Effective and efficient clinical accompaniment, also an important part of clinical education, can be regarded as the means of achieving the aim of integrating theory and practice. Part of theory-practice integration also encapsulates the facilitation and development of personal and professional values and of professionalism in nursing students as future health care professionals. During clinical accompaniment, the student nurse interacts with the community nurse. The purpose of this interaction is, on the one hand, to facilitate knowledge 
and skills development, but on the other to socialise the student nurse to the values of nursing as a profession (Davies 1993:627; Grealish 2000:232). Hence, clinical accompaniment is regarded as a vital component of clinical nursing education as it provides students with opportunities to develop not only the necessary knowledge and skills, but also the necessary sensitivity to the values of those with whom they interact Clinical accompaniment is a deliberative, planned intervention to achieve specific outcomes, which can be orientated towards personal and professional development and socialisation (Edmond 2001:251-252).

Nursing practice does not only depend on technical knowledge and skills; values are inherent to nursing practice, and all these factors together play a significant role in shaping the decisions taken by the nurse. Values, learned through a process of socialisation, shape our worlds of ideas, perceptions, decisions and conduct (Leininger 1978:113; Rassin 2008:615). Hence the facilitation of an environment for adopting professional values and, more specifically, sensitivity to the importance of values in nursing education in general, and clinical nursing education in particular, is important.

Value-sensitive clinical accompaniment in the community nursing environment is important (Leininger 1995:592). In the community nursing environment, students interact with clients and health care professionals from various cultures. Clinical accompaniment in community nursing involves a oneon-one mentoring process by a skilled community nurse or clinical preceptor in the context of a community clinic or health care clinic in a community. The purpose is to develop specific professional competencies and the professional socialisation of students in the community nursing environment. For clinical accompaniment in community nursing to be effective, a respectful relationship grounded in ethical, personal and professional values is required. For preceptors and students to engage with each other effectively during the clinical accompaniment, they need to understand and demonstrate a sensitivity to and respect for each other. This implies that both parties have to become aware of the other's values and of the values within the context in which they interact. This awareness will enable both parties to become sensitive to the diversity of values inherent in the clinical accompaniment process and context. The rationale for value-sensitive clinical accompaniment in community nursing can be based on the following arguments

Culturally diverse nursing workforce and a changing community nursing environment: Values emerge from a person's cultural environment, social groups, education and past experience, and define social and professional behaviour and affect moral judgement (Leininger 1978:113; Rassin 2008:615). Community nurses engage with people from diverse cultural backgrounds. Hence, one may argue that a plurality of values and value systems will be evident when people from diverse cultures engage with one another. The potential for conflict between values may arise in such situations, and this emphasises the need for sensitivity to the values of others. The purpose of the clinical placement of nursing students within the community nursing environment is to enable the students, firstly, to develop specific professional skills and secondly, to develop professional values and an understanding of the cultures and values of the communities with which they interact through a process of socialisation. Gastmans (1998:236-237) is of the opinion that organisations can make it very difficult for nurses to fulfil their ideals of good care. Instead of providing an ethically inspiring environment and atmosphere, the social, interpersonal and institutional environment threatens to create limitations, where any practical exhibition of ethical values, such as respect and caring, becomes extremely difficult and sometimes impossible.

The need to develop a moral and emotionally competent community nurse: A critical outcome for nurses in general is to develop moral and emotional competencies as part of a broader outcomes-based education approach to nursing education in South Africa. Moral competence, according to Jormsi et al (2005:583), can be defined as the ability of the individual to live and act in a manner consistent with a personal moral code and role responsibilities. Moral competence in community nursing practice requires the students to develop a familiarity with and commitment to the values of nursing on the one hand, and to the values of communities, the self and others with whom the students interact on the other hand.

\section{PROBLEM STATEMENT}

Student nurses in a bachelor's degree programme at a university in Gauteng interact with clinical nurses from diverse cultural and value backgrounds during their clinical placement in the community. Anecdotal evidence from discussions with the students during formal theoretical class periods indicates that the students experience value-insensitive treatment during their clinical practice. This is demonstrated by the following anecdote of a student-professional nurse interaction, narrated by a student, which also probes this research:

'One morning, student $X$ was allocated to work with professional nurse $B$ at clinic A. During one consultation session in which the student had to demonstrate her interview skills, the following incident occurred when $\mathrm{Mr}$ Zandile, a Xhosa-speaking client, was seen by both the student and professional nurse B. The professional nurse was fluent in the home language of the client, while the student, who was supposed to conduct the consultation, was not. Without regard for the student, the professional nurse took over the consultation and proceeded with the consultation in the patient's native tongue. The student nurse was excluded from participation in the consultation and no feedback was provided afterwards, which is an indication of the professional nurse's insensitivity towards the student.

Firstly, although the action of the nurse was valid in this case because she probably wanted to assist the patient speedily, the quality of the interpersonal treatment demonstrated by the community nurse towards the student can be criticised. Secondly, this interaction relates to the lack of regard for the needs of the student, both as a learner and as a human being. The exclusion of the student from the interaction and the embarrassment that the student felt in front of the patient demonstrate a lack of professionalism and respect by the community nurse.

Good ethical values are important in any relationship because they set the climate for personal and professional well-being. People ought to be sensitive to the values of other people in order to facilitate good interpersonal relationships, but even more so during student-community nurse interaction. The reason is that not only will the students' learning be affected, but also their socialisation as professional nurses.

From the above introduction and problem statement, the following questions are evident:

- Are community nurses sensitive towards the values of students during student-community nurse interaction in clinical accompaniment in community nursing science practice?

- How do nursing students experience community nurses' sensitivity towards professional values during clinical accompaniment in the community nursing environment?

\section{PURPOSE AND OBJECTIVE}

The purpose of this study was to explore and describe student nurses' experiences of value-sensitive clinical accompaniment in community nursing science during student-community nurse interaction. 


\section{DEFINITION OF CONCEPTS}

\section{Values}

Values are the standards that individuals use to evaluate their own and other people's behaviour and are based on culture. According to Hattingh (1991:39), values are the preferences, moral convictions, principles and standards of a group or an individual. 'Values are rooted in the very conditions of human existence' (Maslow 1959:151). Values serve as governing norms for behaviour (Gross 1994:87).

\section{Value sensitivity}

Value sensitivity refers to the recognition and awareness of the significant values (e.g. diversity and respect) that affect an individual's life during interpersonal encounters (Chrisman 1991:36-37; Leininger 1995:2).

\section{Value-sensitive clinical accompaniment}

Value-sensitive clinical accompaniment is defined as an interactive value-clarification process of planned interventions to achieve specific competencies, in order to develop and demonstrate an understanding of and respect for a diversity of values within a diverse socio-cultural context (Leininger 1995:592; Nies \& McEwen 2007:114; 210).

\section{Value clarification}

Value clarification in community nursing is a process by which student nurses and others identify, examine and develop their own individual professional values. This promotes their personal and professional growth by fostering awareness, empathy and insight (Kozier et al. 2004:70; Nies \& McEwen 2007:210).

\section{RESEARCH METHOD AND DESIGN}

A contextual, qualitative, exploratory and descriptive research design was used. The researcher thus aimed to provide an exploration and description of student nurses' experiences of value-sensitive clinical accompaniment in community nursing during student-community nurse interaction (Burns \& Grove 2005:232).

\section{Population and sample}

The target population consisted of students (representative of different race, language and cultural groups) in their second and fourth years of study in the bachelors and diploma programmes in nursing at two higher education institutions in Gauteng, namely a large, comprehensive university in Johannesburg and a nursing college associated with this university. A nonprobability and convenient sample $(N=9)$ was drawn from the target population. Eligibility criteria for inclusion were that the students must have been formally registered students and in the community nursing science programme at the time of data collection. First- and third-year students were excluded because the course in community nursing science is presented in the second and fourth years of study at both educational institutions. In terms of their course requirements the students have to complete between six and $40 \mathrm{~h}$ of clinical practicals per week in approved community clinics at the district level in Gauteng. In terms of the agreement, a coordinator appointed by the educational institution coordinates the clinical placements of the students. The lecturer liaises with the district-level coordinator who is responsible for assigning the students to a community nurse in the clinic that accompanies the students on a day-to-day basis during their clinical learning. The students and community nurses who interact during these clinical accompaniment encounters are from various population groups. Although there is the possibility of more than one personal value system based on a person's culture, this study focused on sensitivity towards professional values, which both the students and the community nurses ought to share (Mellish, Brink \& Paton 1998:213).
The population for the focus group interviews consisted of B.Cur. students from a university (due to availability) who were exposed to community nursing science practicals at comprehensive health clinics in the Gauteng province. A non-probability, purposive sampling method was followed (Burns \& Grove 2005: 252). Students who were exposed to community nursing practicals in the period from June 2002 to December 2002 were invited to take part in the focus group interviews. The first focus group interview consisted of six students, all Afrikaans-speaking (thus open communication could be facilitated). The second focus group interview consisted of seven English-speaking students. Both focus groups were homogenous because they were from the same academic institution and language group. The students who participated in the focus group interviews were exposed to different clinics in Gauteng, with different clinical accompaniers, which was valuable as different perspectives with regard to clinical accompaniment were obtained. After the second focus group interview the data were saturated (the same themes were occurring) (De Vos 1998:317)

\section{Data collection}

Three methods of data collection, that is, participant observation, field notes and focus group interviews, were used to answer the research questions. The first two data collection methods were employed to answer the first question, namely to identify the professional and personal values that underlie studentprofessional nurse interaction in community nursing. Two focus group interviews were conducted to explore and describe the students' experiences of the extent to which the interaction during clinical accompaniment was value sensitive according to these values.

Participant observation (De Vos 1998:277) was employed as a research method to collect data on the students' perceptions of value-sensitive clinical accompaniment during the studentcommunity nurse interaction in the community nursing environment. Nine video recordings of different studentcommunity nurse interactions were made to capture data. Video recordings provide highly accurate documented data of studentprofessional nurse interaction (De Vos 1998:329-331; Leininger 1995:338; Morse 1994:224-258). The video recordings were made following the guidelines for using video recording as a research method for data collection (Heacock, Souder \& Chastain 1996:334-339; Roberts, Srour \& Winkelman 1996:336-338). These recordings were later analysed for value-sensitive clinical accompaniment. After each recorded interaction, the researcher made field notes of the interaction observed to prevent any loss of valuable information about the interaction. In order to answer the second question (to determine how nursing students experience sensitivity towards professional values by professional nurses during clinical accompaniment in community nursing), focus group interviews were used as a method of data collection. The focus group interviews were conducted by an independent moderator and audio taped. One central question was asked: 'How was sensitivity towards professional values by professional nursing during clinical accompaniment for you?' Data analyses were conducted once the data collection was complete.

At the end of the focus group interviews, the researcher compiled field notes that comprised observations such as hesitation, crying, laughing or other non-verbal cues. Personal notes, which included his or her own reflections and experiences during the course of the interviews, were kept by the researcher.

\section{Data analysis}

Data analysis of the video recordings proceeded inductively (Morse 1994:254). According to Morse (1994), the researcher identifies and describes important segments of the video recording during the inductive descriptive phase of analysis, and observes the extent of regularity in the interaction behaviour. This descriptive task entails more than just the compilation of a 
recording of objective manifestations of behaviour, but can also include non-verbal communication, such as attitudes and verbal communication (Morse 1994:254). During this analysis process, the researcher watched and listened to the interaction between the student and the community nurse in the video recordings so as to be able to describe specific patterns of behaviour or interactive segments. These observations were used as a basis for reaching conclusions about the organisation of behavioural interactions that reflected certain values. The individuals attitudes and behaviours, both, are influenced by their value system. Hence, one can deduce individuals' values by observing their behaviour, as well as their demonstration of sensitivity towards professional values (Hattingh 1991:98-99). These processes were carried out separately by both the researcher and the external expert coder (Lincoln \& Guba 1985:290). During the process of data analysis, triangulation was done between the video recordings and the field notes. To reach conclusions about the sensitivity towards values that underlie the observed and verbalised student-community nurse interaction, the researcher and the external co-coder held a consensus conversation (Lincoln \& Guba 1985:290).

The open coding method described by Tesch (in Creswell 1994:155) was used to identify and analyse the content of the focus group transcripts. Field notes were typed verbatim. Transcripts were read through carefully to obtain an overall idea of the data, while ideas were jotted down as they emerged from the text. During the analysis, the researcher asked herself 'what is the interview about?' and 'what is the underlying meaning?' and wrote notes in the margin. Similar themes that emerged were clustered together by arranging them into major unique and leftover themes. These themes were coded. With the coded themes, the researcher went back to the collected data and read through it again, this time writing the codes next to the appropriate segments in the text. With this organising scheme, new subcategories emerged, which were then grouped into three main categories.

\section{DISCUSSIONS OF RESULTS}

The general findings indicate that clinical accompaniment in community nursing is not value sensitive. The emerging themes describe the students' experiences of value-sensitive clinical accompaniment during student-community nurse interaction in community nursing. As can be seen in Table 1 , three values related to the students' experiences of valuesensitive clinical accompaniment emerged: respect during clinical accompaniment, value-sensitive communication during clinical accompaniment and sensitivity to the quality of clinical accompaniment.

\section{Respect during clinical accompaniment}

The students in community nursing identified respect as a key professional value when interacting with community nurses during the clinical accompaniment. The following excerpts from the empirical data support this observation':

'Sy het my heeltyd geïgnoreer. Sy het nie eers my vrae beantwoord nie' and 'Sy was so haastig en ongeskik en het my nie aan enige verpleegaksies laat deelneem nie.' ['She ignored me the whole time.

TABLE 1

Categories and themes regarding the students' experiences of value-sensitive clinical accompaniment

\begin{tabular}{lll}
\hline Category & Themes \\
\hline Respect during clinical & $\cdot$ & Respect for students \\
accompaniment & - & Respect for patients \\
Value-sensitive communication & $\cdot$ & $\begin{array}{l}\text { Non-verbal communication as } \\
\text { evidence of attitudes of community } \\
\text { nurses and students }\end{array}$ \\
& $\cdot$ & $\begin{array}{l}\text { Verbal communication during clinical } \\
\text { accompaniment }\end{array}$ \\
Sensitivity to quality of clinical & Provision of meaningful clinical \\
accompaniment & & $\begin{array}{l}\text { learning opportunities in clinical } \\
\text { practice } \\
\end{array}$ \\
& Quality during clinical accompaniment \\
\hline
\end{tabular}

She did not even answer my questions' and 'She was in such a hurry and rude; she did not allow me to partake in any nursing actions]

Allan, Tschudin and Horton (2008:553) indicate that respect is a key value espoused by nurses in their conduct with patients and others, and that they consider it to be the essence of nursing (Gallagher 2004:591; Lindh, Severinsson \& Berg 2007:134). However, the experience of students in the community nursing environment during their interaction with community nurses contradicts this statement.

Respect, a value espoused by Immanuel Kant (Anderson 2002), is closely associated with personhood. The latter concept, which is associated with respect, has received tremendous attention from contemporary philosophers working in applied ethics, like nursing ethics. Personhood is defined by Kitwood (in Gallagher 2007:363) as 'a standing or status that is bestowed on one human being, by others, in the context of relationship and social being. It implies recognition, respect and trust.' Hence, personhood as a legitimate object of respect can, on one hand, be viewed from a detached and autonomous perspective, and on the other hand, from the perspective of an interdependent and interconnectedness of human life (Gallagher 2007:363). These hold implications for the interaction between student and community nurse and for the experience of value-sensitive clinical accompaniment in community nursing. If the community nurse views the student from a detached point of view, there is the possibility of a non-caring attitude and this might be perceived by the student as being disrespectful. The effects of a detached view of the personhood of the student are further complicated by the power distance between the community nurse and the student during the clinical accompaniment. Examples of this are that the students' learning needs might be regarded as being less important or that they are viewed as being of lesser importance as human beings. These are supported by the following excerpts from the students' experiences of professional values experienced during clinical accompaniment:

'She put you in a little corner and that is where you stay for the day.'

'I had an experience where they left me in a room by myself ... I'm sitting in her office waiting.'

Such disrespectful treatment has the potential to diminish the students' potential to flourish or learn during the clinical accompaniment and to make them feel vulnerable, and could lead to harmful conduct, which can be devastating for the students (Gallagher 2007:369). Such a view of respect is very constricting. The community nurses interact with students during the clinical accompaniment and, although the students are not autonomous professionals, they still require meaningful guidance from the community nurses. Furthermore, the community nurses are in a position of power in relation to the students during the clinical accompaniment and this places an immense responsibility on the community nurses to be mindful of how they interact with the students. Hence a view of respect that is based on interdependence and interconnectedness will allow the community nurses to understand the students and share the values of nursing with the students in a professional manner. If the community nurses can respect the students in this manner they will recognise them as eminent conversationalists.

In contrast, the lack of an interdependent and interconnected relationship with and respect for the students has the potential to impact negatively on their learning experience. Insensitivity to respect as a value and an attitude, which amounts to disrespect, was a theme that constantly emerged from the empirical data. The students alluded to situations in which they experienced disrespect in their interactions with the community nurses during their clinical accompaniment. The following excerpt supports this:

All quotes in brackets and italics represent free translation from Afrikaans into English 
'Sy laat ons so eenkant sit, met haar en die pasiënt se rûe weggedraai van my. Sy het nie een keer na my gekyk of met my gepraat nie.' [She made us sit to one side, with her and the patient's backs turned away from me. Not once did she look at me or speak to me].

Respectfulness, according to Gallagher (2007:369), contributes to people flourishing. Acting respectfully towards the students requires effort, through paying close attention to them, getting to know them in their individuality, listening actively, taking them seriously and working with them to respond appropriately to the patients' needs. Hence, respect for the student nurses as human beings relates to communication with them, whether verbal or non-verbal.

\section{Value-sensitive communication during clinical accompaniment}

Communication refers to a process of generating and conveying meaning, and is more than only the simplistic transmission of verbal and non-verbal messages from the sender to the receiver. Both verbal symbols and non-verbal cues, such as facial expressions, body language and eye contact, are meaningful and assist with interpretation during communication. Non-verbal cues can be interpreted differently by different cultural groups (Johnson 1990:106).

The second category (value-sensitive communication) reveals that there are positive aspects regarding as well as obstacles to value-sensitive communication in the student-community nurse interaction during clinical accompaniment. Value-sensitive communication is important during the clinical accompaniment of students in community nursing, because it facilitates effective learning, understanding of students and patients, comprehension of situations and effective consultation. One such positive effect of value-sensitive communication during clinical accompaniment on student learning is evident from the following excerpt:

'Sy [die professionele verpleegkundige] het mooi aan my verduidelik wat om te doen. Sy het selfs wenke gegee van dinge waarop ek bedag moet wees.' [She (the professional nurse) explained to me nicely what to do. She even gave me tips about things that I should be cognisant of ]. [It was evident in the video clip that the nurse maintained good eye contact with the student and sent a non-verbal message of recognition.]

However, some students alluded to experiences of valueinsensitive communication during clinical accompaniment. The following excerpt supports this:

'Hulle [die professionele verpleegkundiges] behandel die pasiënt in hulle eie taal... sy sal die hele tyd met haar pasiënt in ' $n$ swart taal gesels en ek moet maar daar sit en intelligent lyk.' [They (the professional nurses) treat patients in their own language... she will speak to her patient in their native language and I must sit and look intelligent].

...ek hou dit nie teen haar nie, want ek weet dit neem te lank om alles te vertaal, maar dit het tog vir my soos ' $n$ gemorste dag gevoel.' [...I cannot hold it against her, because I know it takes a long time to translate everything, but it felt to me like a wasted day].

Communication contains both verbal and non-verbal aspects. The community nurse should be mindful of non-verbal aspects of communications, such as attitudes. From the above quote it is evident that, although the community nurse acted respectfully towards the patient, she excluded the student as an eminent conversationalist in this situation, and this did not contribute to effective clinical learning. The community nurse has to be mindful and act responsibly to create a climate in which recognition is given to the ideas of the student and the student is encouraged to give his/her input in providing effective consultation to the patient (Miles 2008:43-44). The students alluded to various other instances of non-verbal communication in which the community nurses demonstrated insensitivity towards professional values through body language, eye contact and positioning. The following excerpts support this observation:

'Her [the professional nurse's] facial expression indicated that she was not in the mood for students' and 'She was [during the conversation] hammering with her fingers on the table.'

A second theme (from Table 1) that demonstrates valueinsensitive communication during clinical accompaniment relates to verbal communication. Verbal communication is communication through the medium of the spoken or written word (Tjale \& De Villiers 2004:113). In the community clinic where the students are placed, the diverse community of people speak several languages. An example of value-insensitive communication during clinical accompaniment relates to the use of a language unknown to the students, and to the lack of listening skills. The following excerpts from the empirical data support this observation:

'As die pasiënte inkom vir hulle pille of so iets soos dit, dan het sy soos op die pasiënte geskreeu.' [When patients come in for tablets or something like that, then she shouted at the patients].

From the video clips it is evident that the nurses use medical terminology unknown to the students. This was supported by the students reporting that the nurses used terminology without explaining the meaning. Furthermore it was said:

'En sy [die professionele verpleegkundige] luister nie na die pasiënte nie. En die pasiënt gaan weg sonder dat sy regtig aan sy werklike probleem aandag gegee het.' [And she (the professional nurse) does not listen to the patients. And the patient leaves without his real problem being addressed].

Angeles-Llerenas et al. (2003:1312) indicate that, when a high value is placed on value-sensitive communication, nurses, including student nurses, experience less stress and are able to function more independently. This improves relationships. Engagement during a conversation situation between the community nurse and student in community nursing environment is acknowledged. In this vein, Stuhlmiller (in Gallagher 2007:365) relates engagement to the giving of 'full attention' on the part of the community nurse. This supports the importance of verbal and non-verbal cues as elements of value-sensitive communication during clinical accompaniment. Furthermore, engagement requires the community nurses to learn about the students' unique perspectives and to respect them as valid and meaningful, which links value-sensitive communication to respect.

\section{Sensitivity to the quality of clinical accompaniment}

The students were of the opinion that the provision of meaningful clinical learning opportunities by the community nurse was important. By 'meaningful' they meant that the quality of clinical accompaniment ought to be a value that the community nurses in the community nursing environment should uphold. Hence the students regarded quality clinical accompaniment as an important professional value.

'They must allocate you to a person [professional nurse] that is willing to show or guide you'; 'Ek [die student] is in die kantoor gelaat en het rekenaarspeletjies gespeel die hele oggen; dit was onaangenaam'; [I (the student) was left in the office and played computer games the whole morning; it was unpleasant);

'Ons [die studente] het die hele tyd net stoor reggepak.' [We (the students) had to clean the store room the whole time];

'Most of the time you [students] only observed what they were doing.'

'There was no supervision, but at the same time if I had a problem they [the community nurses] were there so that I could go and ask - it would take a while and it wasn't nice.'

Quality, according to Sherwood (2008:414), measures the gap between what is desired, the ideal, and what is the reality. This is in line with the views of the students, who felt that quality was a desired professional value during the clinical accompaniment. However, the reality was that the students experienced the opposite. This contributes to the gap between the quality that 
is desired during clinical accompaniment and what is actually happening. Elsewhere, value-sensitive clinical accompaniment has been defined as a planned process of interventions to achieve specific competencies, including the development of professional values as a nurse. Quality, identified by students as an important value during value-sensitive clinical accompaniment, also refers to the quality of the interaction between the students and the community nurses. This emphasises the interpersonal aspects of clinical accompaniment, which enable the students to discuss their clinical learning experiences with the community nurses, a process that also involves reflection (Bezuidenhout 2003:12). Value-sensitive clinical accompaniment as a reflective process of learning facilitation requires the community nurses to identify with the students during clinical accompaniment Reflection on personal and professional values during clinical accompaniment, grounded in respectful conduct and sensitivity to communication, fosters quality value-sensitive clinical accompaniment (Feraghty \& Bayes 2009:33).

Clegg (2000:43) demonstrated a correlation between quality and morale within health care situations, such as in studentcommunity nurse interaction during clinical accompaniment. In this vein, poor morale amongst students due to the quality of their clinical accompaniment by community nurses has an impact on their perceptions of value-sensitive clinical accompaniment of a high quality. Furthermore, Redman (2008:222) maintains that clinical experience is generally viewed as an important indicator of clinical competence, the latter being the outcome of value-sensitive clinical accompaniment. Thus, if the experience of the student is negative regarding the quality of the clinical accompaniment in terms of values, then it can reasonably be concluded that the achievement of competencies as an outcome of value-sensitive clinical accompaniment is in jeopardy.

\section{ETHICAL CONSIDERATIONS}

Participation in this study was voluntary and the study received approval on 11 March 2002 from the Faculty Academic Ethics Committee at the then Rand Afrikaans University.

The researcher adhered to the following:

- The right to self-determination, which is based on the ethical principle of respect for persons. The researcher treated the participants in this study as autonomous agents by informing them about the proposed study and pointing out that their voluntary participation or withdrawal from the study at any time would not jeopardise them (Polit \& Hungler 1999:139).

- The right to privacy of the participants was ensured by closing the doors of the consultation rooms whilst video recordings were being made of the nurse-patient consultations. The participants were also informed that they could withdraw from the study at any time. The participants were assured that the video recordings and audiotapes of the focus group interviews would only be used for the purpose of the study. The tapes were numbered so no names would be made known (Polit \& Hungler 1999:139).

- The right to anonymity and confidentiality. Complete anonymity could not be assured in this study, as video recordings were made of the consultations between the patients, community nurses and student nurses. However, the participants were asked for verbal consent to guard their partial anonymity. The tapes were numbered to ensure confidentiality and the participants were informed that only the researcher and the external coder would watch the video recordings and listen to the audiotapes of the focus group interviews. Furthermore, the participants were assured that the videotapes and audiotapes would only be used for the purpose of this study and would be destroyed on completion of the study (Polit \& Hungler 1999:139).

- The right to fair treatment, which is based on the ethical principle of justice. The participants in this study were selected on the basis of the eligibility criteria (Polit \& Hungler 1999:138).
- The right to protection from discomfort and harm, which is based on the ethical principle of beneficence, and holds that one should do good rather than harm. The participants in this study were exposed to the mere inconvenience of having to spend some time and the possible temporary discomfort of being video-recorded, observed and audio-taped (Polit\& Hungler 1999:134)

\section{TRUSTWORTHINESS}

During the research, trustworthiness was ensured by means of the strategies for trustworthiness devised by Lincoln and Guba (1985:289-331), namely credibility, dependability, ability to confirm and transferability.

- Co-coding was conducted by an independent coder. A full set of video recordings, field notes and verbatim transcripts of the focus group interviews was given to the independent coder, together with the purpose of the study. After both the independent coder and the researcher had coded the transcripts and identified the themes and categories, a consensus discussion was held. The aim of the discussion was to compare and justify how both parties arrived at the themes and subcategories, and to achieve consensus on the final categories of experiences. The researcher attended specific training on the making of video recordings. A pilot recording of a mock student-community nurse interaction was made. Prolonged engagement was achieved with extra time being allocated to video recordings to capture additional data. The recording allowed the researcher and the co-coder to play back and revisit frames during the data analysis to capture the meaning more effectively. For audit trail purposes, adequate reference was made to the literature sources used during the conceptualisation of the categories.

\section{LIMITATIONS OF THE STUDY}

A limitation of this study relates to the sample size and the composition of the student groups. The findings therefore cannot be generalised to all contexts. However, this study was contextual, as it emanates from a particular problem being identified in a specific context.

\section{RECOMMENDATIONS}

It is recommended that a similar study regarding value-sensitive clinical accompaniment be conducted with a more representative sample of the student population. The formulation of guidelines for value-sensitive clinical accompaniment in community nursing is of the utmost importance. These guidelines should focus at the very least on matters of respect and communication during and the quality of clinical accompaniment.

\section{CONCLUSION}

From the above discussion it can be concluded that the facilitation of value-sensitive clinical accompaniment in community nursing, as indicated by student experiences, valuesensitive communication, respect and the quality of clinical accompaniment, is important. The professional socialisation of students to become value-sensitive practitioners, a process undertaken by community nurses in the community nursing environment, should take this into consideration. The values of all the parties involved in nursing actions influence the outcome of the action and thus it is essential that, in every nursing situation, the community nurses reflect on their values and attempt to enter nursing situations with an open, unbiased attitude, to offer optimal care to the patients and to facilitate the students' learning (Gross 1994:74, 75). This is important because it provides the students with meaningful competencies to improve their caring. It is essential that the clinical accompanier create a supportive, non-threatening environment that will 
allow the students to feel at liberty to ask questions and to take part in clinical community nursing actions under the direct supervision of the community nurses. The community nurses are role models and therefore should be sensitive to their own attitudes and actions during the clinical accompaniment. To assist the community nurses, as facilitators of the clinical learning of students in community nursing, there should be guidelines for value-sensitive clinical accompaniment that are based on the findings of this research. The guidelines for valuesensitive clinical accompaniment in community nursing science will be provided in a follow-up article.

\section{REFERENCES}

Allan, H., Tschudin, H. \& Horton, K., 2008, 'The devaluation of nursing: A position statement', Nursing Ethics 15(4), 549-556.

Anderson, J., 2002, 'Lecture notes on Kant's Ethics', SETIS, viewed 05 February 2002, from http://www.purl.library. usyd.edu

Angeles-Llerenas, A., Alvarez del Rio, A., Salazar-Martinez, E. \& Kraus-Weissman, A., 2003, 'Perceptions of nurses with regard to doctor-patient communication', British Journal of Nursing 12(22), 1312-1321.

Bezuidenhout, M.C., 2003, 'Guidelines for enhancing clinical supervision', Health SA Gesondheid 8(4), 12-23.

Burns, N. \& Grove, S.K., 2005, The practice of nursing research. Conduct, critique, and utilisation, Elsevier Saunders, New Jersey.

Chan, M., 2002, 'Development of the clinical learning environment inventory: Using the theoretical framework of learning environment studies to assess nursing students' perceptions of the hospital as a learning environment', Journal of Nursing Education 41(2), 69-75.

Chrisman, N.I., 1991, 'Culture-sensitive nursing care', in M. Patrick, S.L. Woods, R.F. Craven, J.S. Rkosky \& P.M. Vruno (eds.), Medical surgical nursing: Pathophysiological concepts, 2nd edn., pp. 36-37;45-46, Lippincott, Philadelphia.

Clegg, A., 2000, 'Leadership: Improving the quality of patient care', Nursing Standard 14(30), 43-45.

Creswell, J.W., 1994, Research design: Qualitative and quantitative approaches, Sage, London.

Davies, E., 1993, 'Clinical role modeling: Uncovering hidden knowledge', Journal of Advanced Nursing 18, 627-636.

De Vos, A.S., 1998, Research at grass roots: A primer for the caring professions, Van Schaik, Pretoria.

Edmond, C.B., 2001, 'A new paradigm for practice education', Nurse Education Today 21, 251-259.

Feraghty, S.M. \& Bayes, S., 2009, 'An Australian perspective: The art of being with students', The Journal of Continuing Education in Nursing 40(1), 22-38.

Gallagher, A., 2004, 'Dignity and respect for dignity - two key health professional values: Implications for nursing practice', Nursing Ethics 11(6), 587-599.

Gallagher, A., 2007, 'The respectful nurse', Nursing Ethics 14(3), 361-371.

Gastmans, C., 1998, 'Challenges to nursing values in a changing nursing environment', Nursing Ethics 5(3), 236-245.
Grealish, L., 2000, 'The skills of coach are an essential element in clinical learning', Journal of Nursing Education 39(5), 231-233.

Gross,E.J.,1994,"nRadikalestrategievirgesondheidsvoorligting', DCur dissertation, Department of Nursing, Rand Afrikaans University, Johannesburg.

Hattingh, L., 1991, "n Teorie van waardes', DEd dissertation, Department of Humanities, Rand Afrikaans University, Johannesburg.

Heacock, P., Souder, E. \& Chastain, J., 1996, 'Subjects, data, and videotapes', Nursing Research 45(6), Nov/Dec 336-338.

Johnson, D.W., 1990, Reaching out: Interpersonal effectiveness and self-actualization, Prentice Hall, London.

Jormsi, P., Kunaviktikul, W., Ketefian, S. \& Chaowalit, A., 2005, 'Moral competence in nursing practice', Nursing Ethics 12(6), 582-594.

Kozier, B., Erb, G., Blais, K. \& Wilkinson, J.M., 2004, Fundamentals of nursing concepts: Process and practice, 5th edn., AddisonWesley, New York.

Leininger, M., 1978, Transcultural nursing: Concepts, theories and practices, Wiley Medical, New York.

Leininger, M., 1995, Transcultural nursing concepts: Theories, research $\mathcal{E}$ practices, Greyden Press, New York.

Lincoln, Y.S. \& Guba, E.G., 1985, Naturalistic inquiry, Sage, Beverly Hills.

Lindh, E., Severinsson, E. \& Berg, A., 2007, 'Moral responsibility: A relational way of being', Nursing Ethics 14(2), 129-140.

Maslow, A.H., 1959, New knowledge in human values, Harper \& Row, New York.

McCarty, M. \& Higgins, A., 2003, 'Moving to an all graduate profession: Preparing preceptors for their role', Nursing Education Today 23, 89-95.

Mellish, J.M., Brink, H.I.L. \& Paton, F., 1998, Teaching and learning: The practice of nursing, Heinemann, Johannesburg.

Miles, J. 2008, 'Effective communication', Practice Nurse 35(2), $42-47$.

Morse, J.M., 1994, Recent advances in nursing: Issues in crosscultural nursing, Longman, Singapore.

Nies, M.A. \& McEwen, M., 2007, Community/public health nursing, promoting the health of populations, 4th edn., Elsevier Saunders, Houston, Texas.

Polit, D.F. \& Hungler, B.P., 1999, Nursing research: principles and methods, Lippincott, Philadelphia.

Randse Afrikaanse Universiteit (RAU), 2002, Etiese Standaarde, Randse Afrikaanse Universiteit, Johannesburg.

Rassin, M., 2008, 'Nurses' professional and personal values', Nursing Ethics 15(5), 614-630.

Redman, RW., 2008, 'Experience and expertise: How do they relate to quality and safety?' Research and Theory for Nursing Practice 22(4), 222-225.

Roberts, B.L., Srour, M.I. \& Winkelman, C., 1996, 'Videotaping: An important research strategy', Nursing Research 45(6) Nov/Dec, 334-338.

Sherwood, G., 2008, 'Transforming health care through quality', Urologic Nursing 28(6), 414-416.

Tjale, A. \& De Villiers, L., 2004, Cultural issues in health and health care: A resource book for Southern Africa, Juta, Johannesburg. 